\title{
EFFECTIVENESS OF CHRONIC DISEASE CONTROL CLUB ON BLOOD SUGAR LEVEL CONTROL IN SUKOHARJO, CENTRAL JAVA
}

\author{
Fajar Alam Putra'), Dono Indarto²), Ruben Dharmawan²) \\ 1)Masters Program in Public Health, Universitas Sebelas Maret \\ 2)Faculty of Medicine, Universitas Sebelas Maret
}

\begin{abstract}
Background: Exercise, dietary change, and medications are frequently used in the management of type 2 diabetes. Chronic disease control club (prolanis) is a proactive approach involving health facilities, health insurance, and patients in order to maintain quality of life of chronic disease patients with effective and efficient cost. This study aimed to examine effectiveness of chronic disease control club on blood sugar level control in Sukoharjo, Central Java.

Subjects and Method: This was an analytic observational study with a cross-sectional design. The study was conducted at Sukoharjo community health center, Sukoharjo, Central Java, from August to September 2018. A sample of 245 type 2 DM patients was selected by random sampling. The dependent variable was blood sugar level. The independent variables were physical training, anxiety, chronic disease control club participation, and complication. Data on anxiety was measured by HARS. The other variables were measured by questionnaire. The data were analyzed by a multiple logistic regression run on Stata 13.

Results: Blood sugar level increased with high anxiety $(b=2.78 ; 95 \% \mathrm{CI}=1.30$ to 4.26 ; $\mathrm{p}<0.001)$ and complication $(\mathrm{b}=33.14 ; 95 \% \mathrm{CI}=8.02$ to $58.26 ; \mathrm{p}=0.010)$. Blood sugar level decreased with active participation in chronic disease control club $(b=-30.14 ; 95 \%$ $\mathrm{CI}=-49.09$ to $-11.19 ; \mathrm{p}=0.002)$ and high physical training $(\mathrm{b}=-15.12 ; 95 \% \mathrm{CI}=-19.96$ to -10.27 ; $\mathrm{p}<0.001$ ).

Conclusion: Blood sugar level increases with high anxiety and complication. Blood sugar level decreases with active participation in chronic disease control club and high physical training.
\end{abstract}

Keywords: type 2 diabetes mellitus, blood sugar level, chronic disease control

\section{Correspondence:}

Fajar Alam Putra. Masters Program in Public Health, Universitas Sebelas Maret. Jl. Ir. Sutami 36A, Surakarta 57126, Central Java. Email: bolodewe88@gmail.com.

Mobile: 085867371599.

The $6^{\text {th }}$ International Conference on Public Health Best Western Premier Hotel, Solo, Indonesia, October 23-24, 2019 | 31 https://doi.org/10.26911/the6thicph.01.08 